\title{
Taxonomy and World Distribution of Campylopus introflexus and $C$. pilifer (=C. polytrichoides): a New Synthesis ${ }^{1}$
}

\author{
S. R. GRAdSTEIN ${ }^{2}$ AND H. J. M. SIPMAN ${ }^{2}$
}

\begin{abstract}
Campylopus introflexus (Hedw.) Brid. sensu lato comprises two widespread, closely related species: tropical and warm-temperate C. pilifer Brid. (= C. polytrichoides DeNot.) and temperate southern hemispheric C. introflexus (Hedw.) Brid., which was recently introduced in Europe. Main differences are in the height of the dorsal lamellae of the leaves, in spore size and in seta length. In C. pilifer lamellae are more pronounced in tropical mountains than in lowland areas. An extreme form with lamellae up to seven cells high is C. pilifer var. lamellatus (Mont.) comb. nov. from Bolivia.
\end{abstract}

The recent invasion of Campylopus introflexus (Hedw.) Brid. in Europe (Frahm, 1972) has renewed interest in the taxonomy of this species. Traditionally it was considered an almost cosmopolitan species until Giacomini (1955) showed that two species are at hand: $C$. introflexus s.str., occurring in temperate regions of the southern hemisphere, large parts of America and (at that time!) one locality in Europe (Bretagne), and C. polytrichoides DeNot., occurring in southwestern Europe, Africa and southern Asia. The characteristics used to distinguish the two species, particularly those of the gametophyte, have been questioned by several authors, e.g. Richards (1963), Barkman and Mabelis (1968) and Jacques and Lambinon (1968). Therefore a renewed investigation of the taxonomy of the species was undertaken, simultaneously, by J.-P. Frahm (Duisburg) and the present authors. Frahm's studies were confined to characteristics of the gametophyte, whereas ours also included characteristics of the sporophyte.

As a result of his investigations, Frahm (1974, 1975) showed that: 1. The only reliable differences in the gametophyte between the two species are found in the nerve - the height of the dorsal lamellae, the number of stereids in each group and the width of their lumen. These characteristics are best studied in transverse sections of the upper part of the leaf, near the center of the nerve. Leaves should be taken from just below the comal heads of the stems, since comal leaves ("Hochblätter") of $C$. polytrichoides may resemble leaves of $C$. introflexus. 2 . The distribution of the two species as given by Giacomini is incorrect since C. polytrichoides also occurs in the

${ }^{1}$ This paper is dedicated to the memory of the late Dr. P. A. Florschütz $(\nmid 1976)$, whose guidance and expert knowledge of Campylopus systematics has been of great help. We thank the curators of the herbaria cited in the text for the loan of specimens. For valuable information we express our gratitude to Dr. J. J. Barkman (Wijster), Dr. G. C. S. Clarke (London), Dr. A. C. Crundwell (Glasgow), Dr. E. Hegewald (Dortmund) and especially to Dr. J. -P. Frahm (Duisburg) in close cooperation with whom the work was carried out.

${ }_{2}^{2}$ Institute for Systematic Botany, State University of Utrecht, Heidelberglaan 2, Utrecht, Netherlands. 


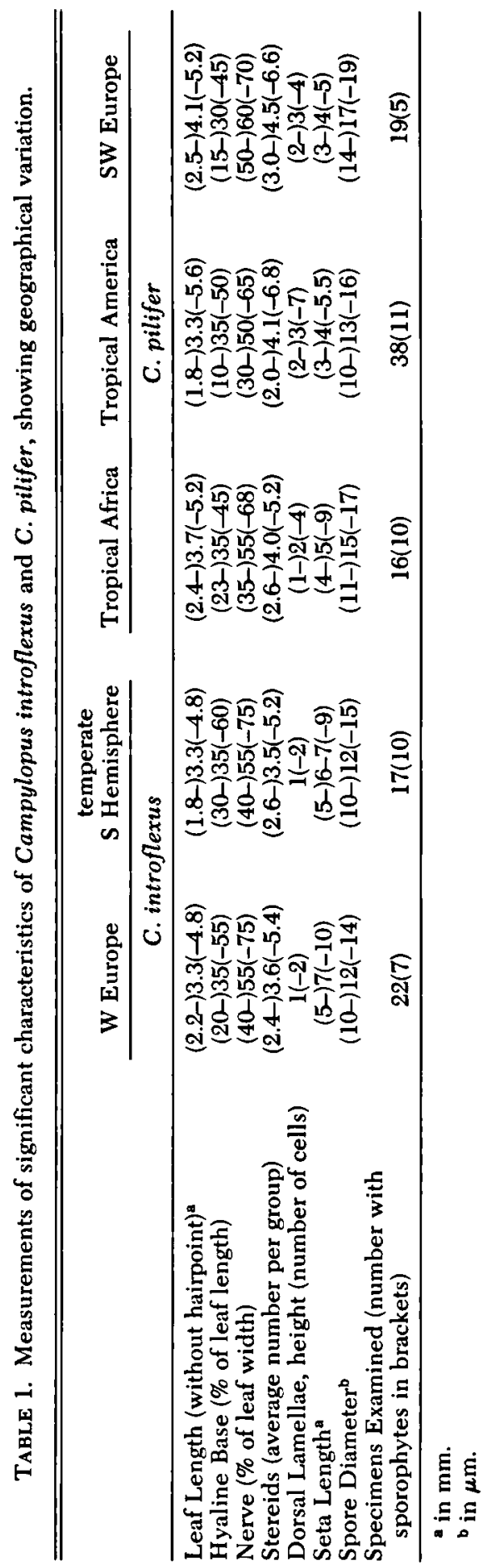


U.S.A. and Central and South America, whereas C. introflexus is restricted to the temperate zone of the southern hemisphere and West and Central Europe. The two species overlap in distribution in Brazil, Uruguay, Argentina, South Africa and, since recent times, in western Europe.

Our studies, based on examination of over 150 collections from all over the world, confirm Frahm's conclusions on the distribution of the two taxa. We also recognize the two taxa as species, although we find fewer gametophytic differences. Measurements of significant characteristics are given in Table 1. Some "classical" characteristics, e.g. reflexion of hairpoints, leaf auricles, width of stereid lumina and length of the convoluted part of the leaf, are omitted because they proved to be less significant, as was also shown by Frahm (1974).

Table 1 shows that material assigned to C. introflexus (Hedw.) Brid.-from the temperate southern hemisphere and from western Europe-is morphologically rather uniform. The remaining material, assigned to $C$. pilifer Brid. $(=C$. polytrichoides DeNot.) is morphologically less uniform, but differs significantly from C. introflexus by the height of the dorsal lamellae, the length of the seta and the diameter of the spores. The differences are summarized in the key given below. Contrary to Frahm (1974) we cannot accept characteristics derived from the stereids as diagnostic, since a considerable overlap among all populations is present.

Nerve in transverse section with dorsal lamellae composed of 2-4 cell rows (5-7 cell rows in var. lamellatus (Mont.) comb. nov.); seta 3-5.5 mm (-9 mm in tropical East Africa!); spores $12-19 \mu \mathrm{m}$ in diam. Tropical and warm-temperate: North and South America, Europe, Africa, India C. pilifer Brid.

Nerve in. transverse section with dorsal lamellae composed of $1(-2)$ cell rows; seta $5-8(-10) \mathrm{mm}$ long (only $4 \mathrm{~mm}$ in var. brachycarpa Giac.); spores 10-15 $\mu \mathrm{m}$ in diam. Temperate southern hemisphere, neophytic in West and Central Europe C. introflexus (Hedw.) Brid.

\section{Campylopus pilifer Brid.}

Lectotype: Italy, "In Insula Ischia ad rupes, Auguste 1806" (B). Syntype: France, "In Sylva prope Fontainebleau, Octobre 1807" (B).

Synonyms (see Frahm, 1975, for complete listing):

Dicranum capitiflorum P. Beauv., Prodr. 53. 1805.

Type: "Bourbon" (Réunion), Bory St. Vincent (PC, in herb. L. C. Richard); non Campylopus capitiflorus Mont., Syll. 42. 1856.

Campylopus longipilus Brid., Bryol. Univ. 1: 447.1826 nom. illeg.

Campylopus polytrichoides DeNot., Syll. Musc. 222.1838.

Campylopus introflexus (Hedw.) Brid. var. cordobaensis Thér., in Bauer, Musci Eur. Am. exsicc. ser. 45, nr. 2204. 1934 syn. nov. Type: Argentina, Cordoba, El Durazno, Hossaeus 149 (isotypes in BM, herb. Frahm).

Description and illustrations: See Grout (1937: 93-94), Giacomini (1955: 55, fig. 1-6), Gangulee (1971: 301-303, fig. 141), Frahm (1974: fig. 6).

Distribution (Fig. 2) and Ecology.-Campylopus pilifer is widespread between $40^{\circ} \mathrm{N}$ and $35^{\circ} \mathrm{S}$ in North and South America, Africa, India and in Europe, where the species has a western-Mediterranean-Atlantic distribution and reaches north to $57^{\circ} \mathrm{N}$. Presumed occurrence in Indomalesia (cf. Gangulee, 1971, map LXXXVI) could not be confirmed. Records from the Netherlands proved to belong to C. introflexus (Hedw.) Brid. (Sipman, 1977). In warm-temperate regions the species occurs at low elevations, whereas in tropical regions it is mainly found at higher altitudes, reaching to $3500 \mathrm{~m}$ in the mountains of Central Africa and the Andes of northern South America.

The species occurs in regions with an, at least periodically, humid climate, on dry, acid, poor mineral soil. It often grows on thin soil covering granite or schistose rock, or in rock crevices, in open woods, heath-islands, etc.; rarely on bases of trees or rotten 




Figure 1. Campylopus pilifer var. lamellatus (Mont.) comb. nov. Transverse section from upper region of leaf, ca. $200 \times$ (from the type collection).

wood. According to Richards (1963) C. pilifer has a narrower ecological tolerance than C. introflexus in Britain and is more thermophytic.

Nomenclature.-When reestablishing Campylopus polytrichoides as a species, Giacomini (1955) placed three older species names in its synonymy without paying attention to priority: Dicranum capitiflorum P.Beauv. 1805 from La Réunion and Campylopus pilifer Brid. 1819 and C. longipilus Brid. 1826 from Europe. We have examined type material of these binomials and found them to fit Giacomini's concept of C. polytrichoides.

Type material of Dicranum capitiflorum was found in the herbarium of L. C. Richard (PC-Gén.), where it was erroneously inserted under Campylopus capitiflorus Mont. The plants are fairly robust, and fruiting stems have distinct comal heads with long, slightly decurved hairpoints, resembling those of $C$. introflexus. However, the 2-3 cell high lamellae, the $5-5.5 \mathrm{~mm}$ setae and, particularly, the spores $(16-17 \mu \mathrm{m})$ indicate typical "C. polytrichoides."

Campylopus pilifer was described by Bridel (1819) on the basis of two collections, one from Italy and the other from France: "In insulâ Ischiâ 1806, et in saxosis sylvae prope Fontainebleau 1807 caespitibus densis pulchre variegatis crescentem sed sine theca inveni" (Mant. Musc., p. 72). He recognized a close relationship of his new species to Dicranum flexuosum var. piliferum Turn. 1804, from Great Britain, based on piliferous specimens from Wales and Ireland (probably C. atrovirens?) and a nonpiliferous plant (C. fragilis?) from the Dillenius herbarium (Turner, 1804: p. 74). In his Bryologia Universa, Bridel (1826) combined C. pilifer with Turner's piliferous specimens from Great Britain into Campylopus longipilus Brid. nom. nov. This name is superfluous since it includes the older binomial C. pilifer, which has priority.

Due to the courtesy of the curator of the Bridel herbarium, Dr. W. Schultze-Motel, we were able to study the original material of $C$. pilifer Brid. The two syntypes, both sterile, fit Campylopus polytrichoides DeNot; the leaves have short hairpoints, short cells, very wide nerves, involuted upper margins and dorsal lamellae of 2-3 cells high. The stereids could not be studied adequately in this old material.

Thus the name Campylopus pilifer Brid. should now be accepted as the correct name for Campylopus polytrichoides DeNot. We have chosen the Ischia collection as the lectotype of $C$. pilifer Brid. because it is the oldest of the two syntype collections.

Variation (Table 1).-The morphological variation of the gametophyte was dis- 


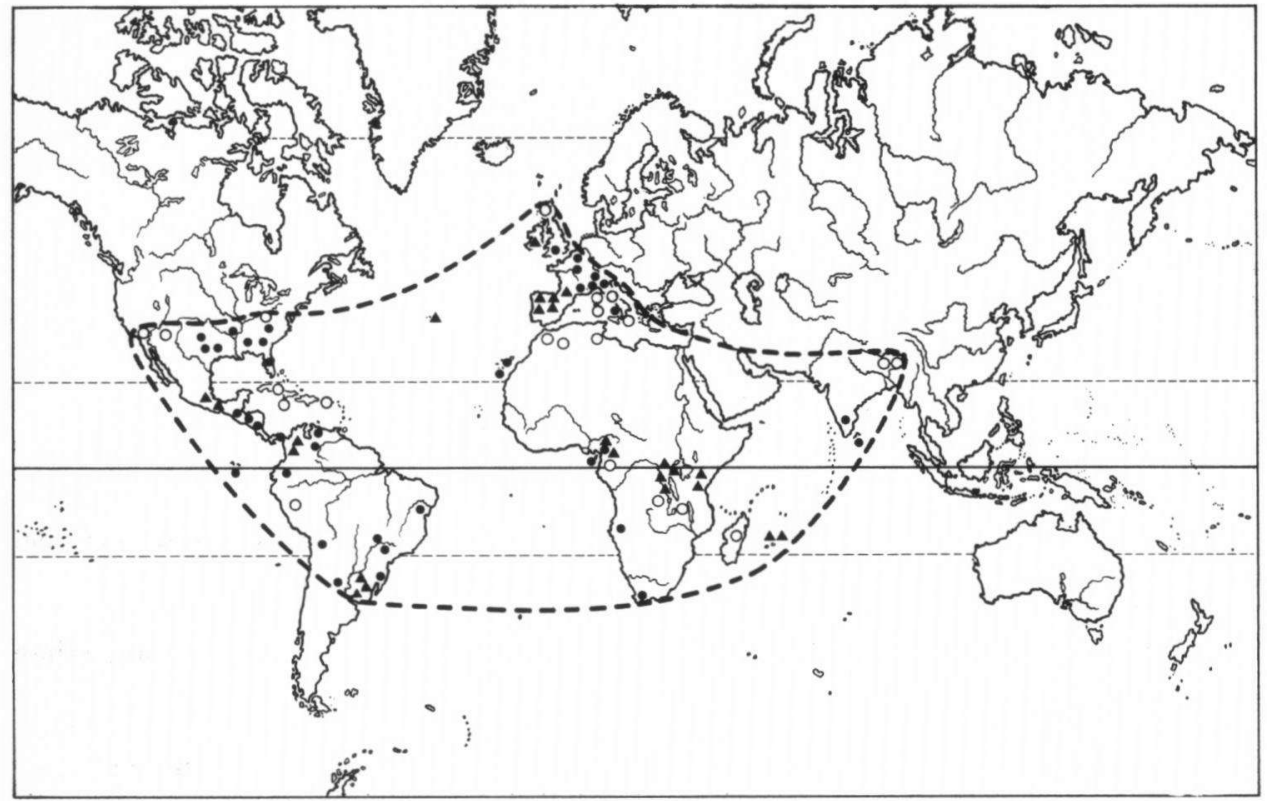

Figure 2. Distribution of Campylopus pilifer Brid. Triangle: Specimens with sporophytes. Solid circle: Non-fruiting specimens. Open circle: Literature record.

cussed by Frahm (1974) and, at length, by Giacomini (1955), who distinguished several intraspecific taxa. From our study of variation it appears that it is virtually impossible to demonstrate clear-cut discontinuities; therefore we have not paid much attention to intraspecific taxa distinguished by earlier authors.

Disagreement among authors exists on the taxonomic position of specimens with high lamellae but relatively wide stereid lumina ("substereids"). Examples are $C$. introflexus var. cordobaensis Thér. from Argentina (Frahm, 1975: fig. 13), C. polytrichoides subsv. daldanianus (DeNot.) Giac. from Italy (Giacomini, 1955: fig. 6), specimens from Central America reckoned with question mark to $C$. polytrichoides by Frahm (1974: fig. 6C-D) and a specimen from Brazil, Porto Alegre (Giacomini, 1955: fig. 11), which was reduced to $C$. introflexus by Giacomini but to $C$. polytrichoides by Hegewald (1973). In our opinion all these specimens belong to C. pilifer. Contrary to Frahm (1974), we do not find the width of the lumina of the stereids or, in other words, the thickness of their walls, a reliable characteristic to distinguish between C. pilifer and C. introflexus. In Campylopus species from Colombia, Florschütz \& Florschützde Waard (1974) found striking variation in the thickness of the walls of the stereids, even within a single specimen! One would assume ecological conditions to cause this variation, but culture experiments did not substantiate this assumption (Florschütz \& Florschütz-de Waard, 1974).

Dorsal lamellae tend to become four cells high in collections from tropical mountain areas between 2000 and $3500 \mathrm{~m}$ (cf. Frahm, 1974: fig. 6D; Bizot, 1973). These collections probably fit $C$. introflexus var. altecristatus Ren. \& Card. from Madagascar. An extreme is a plant from the Bolivian Andes described by Montagne as Campylopus lamellatus (holotype-PC; isotype- $\mathrm{K}$ in $\mathrm{BM}$ ), which has 5-7 cell high lamellae (Fig. 1). The specimens have very slender shoots without distinct comal heads, but other- 


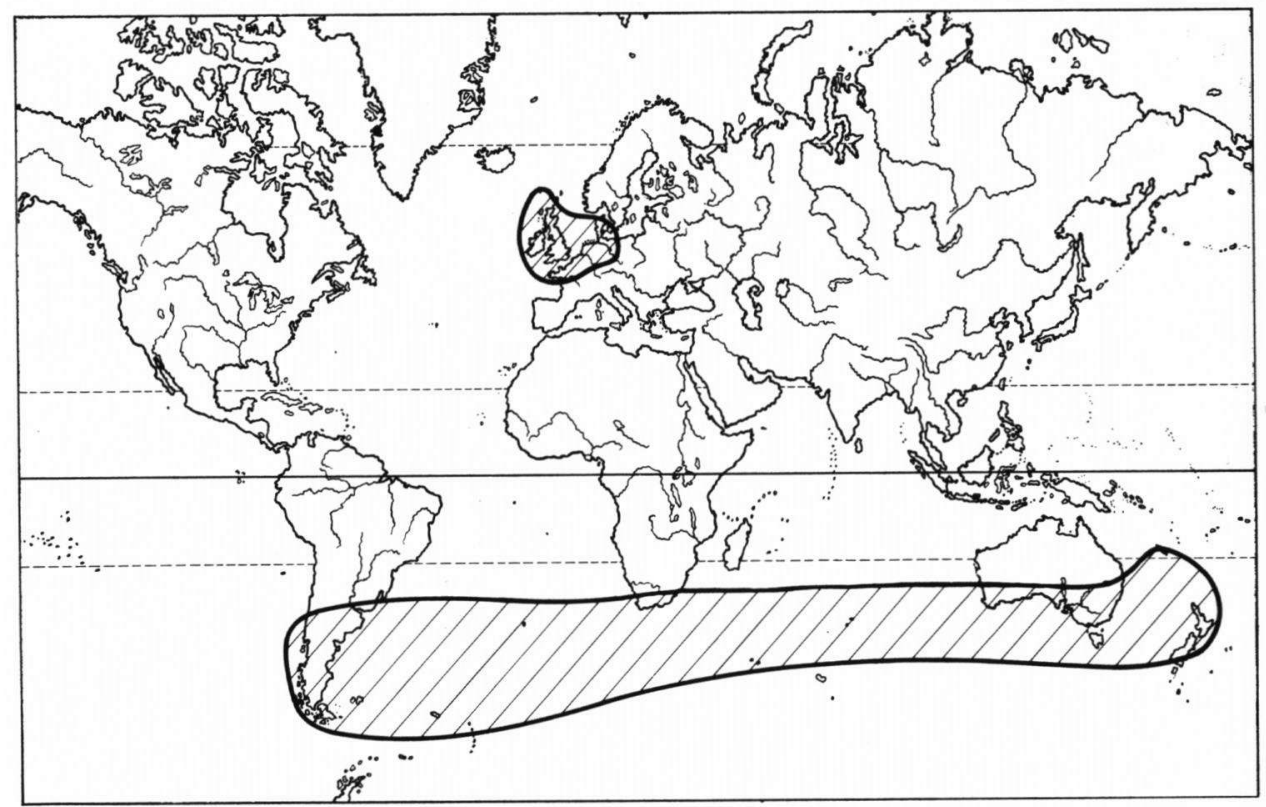

Figure 3. Distribution of Campylopus introflexus (Hedw.) Brid.

wise they fit C. pilifer. Therefore C. lamellatus is reduced to varietal rank under $C$. pilifer: C. pilifer Brid. var. lamellatus (Mont.) Gradstein \& Sipman comb. nov. (basionym: Campylopus lamellatus Mont., Ann. Sci. Nat. Bot. ser. 2(9): 52. 1838).

Sporophyte.-Campylopus pilifer rarely produces sporophytes, contrary to C. introflexus. Up to the present time sporophytes were known only from a few localities in southwestern Europe (Venturi, 1881; Luisier, 1908; Dismier, 1909; Hegewald, 1973). We have located additional collections with sporophytes from Africa, Mexico and South America and have found that seta length varies from $3-5(-5.5) \mathrm{mm}$, whereas spore size ranges from 10-19 $\mu \mathrm{m}$; we cannot confirm sizes of over $20 \mu \mathrm{m}$ given by previous authors (Dismier 1909; Casares-Gil, 1932). A geographic differentiation was found in the spore size, the African and American collections having spores of 10-17 $\mu \mathrm{m}$, the European and Macaronesian collections 14-19 $\mu \mathrm{m}$. Because of the small number of collections available, we consider these differences not significant enough to distinguish geographical races.

It should be noted that in European and African material at least $75 \%$ of the spores, in unopened capsules, are aborted-in the Irish collection recorded by Hegewald (1973) they are totally lacking-whereas in American collections we never saw abnormalities in spore formation. Since abortion of spores is characteristic of hybrid sporophytes, the question rises whether sporophytes in European and African $C$. pilifer are of hybrid origin. Before anything more can be said about this, data should become available on the distribution of the sexes in the field (most Campylopus species, including C. pilifer, are dioicous) and the association with other Campylopus species capable to hybridize with C. pilifer. According to Hegewald (1973) C. pilifer (with sporophytes) from Ireland was growing associated with C. introflexus (c. sp.) and C. brevipilus (ster.). A closer investigation of this Irish locality might prove worthwhile. 
Specimens with sporophytes examined: IRELAND. CORK: Beara peninsula, Hegewald s.n. (Herb. Hegewald, U). France. St. Etienne de Baigony, Dismier (BM, PC). Spain. Pontevedra, Allorge, Bryoth. Iber. $25 b$ (L); St. Jacques de Compostelle, without collector (PC). PORTUGAL. Tamalicao, Moledo do Minho, Machado in Bauer, Musc. Eur. Am. exs. 1905a (L); Beira Alta, Ribeiradio, Sergio 653 (LIsu). Azores. Santa maria: Pico Alto, Monod 15112 (PC); Meio molho, Allorge 61 (PC). Cameroun. Mt. Cameroon, Mann (BM, 2 specimens). KenYa. Mt. Kenya, Schelpe 2570 (PC). Tanzania. Mt. Kilimanjaro, Hedberg 1147 (PC). Ruanda. Préfecture de Cyangugu, forêt de Rugege, De Sloover 18942 (NAM, U). ZAire. Massif du Kahuzi, De Sloover $12544,12545,12561$ (NAM, U). KIVU, entre Goma et Sake, De Sloover 13388 (NAM, U); Mont Biega, De Sloover 12966 (NAM, U). RÉunion. Bory St. Vincent (PC); Piton Mare-à-Boue, De Sloover 17285 (NAM, U).

Mexico. michoacan: Morelia, Arsène 7862 (PC); moRelos: N. of Guernavaca, Hermann 20939 (TENN, U); OAXACA: Ixtlan, Delgadillo 132a (TENN, U); $112 \mathrm{~km}$ from Tuxtepec towards Oaxaca, Manuel 644 (LAF, U); VerachuZ: La Joya near Jalapa, Sharp et al. (TENN, U); Sierra de San Esteban, near Guadajara, Pringle 10568 (L). Colombia. Cundinamarca: Torca, Cleef 29 (U); Páramo Cruz Verde, Cleef 3015 (U). Brazil. Rio grande do sUl: Tapes, Vital 2034 (SP). Uruguay. Arroyo Piedras, Herter 1437 (gOet, U); Florida, La Palma, Herter 99434 (B). PERu. URUBamba: Machu Picchu, Hegewald 5585 (Herb. Hegewald, U).

Campylopus introflexus (Hedw.) Brid.

Basionym: Dicranum introflexum Hedw., Sp. Musc. 147. 1801.

Type: Australia, "Nova Hollandia" (G, sheet 1 "A", fide Richards, 1963).

Synonyms: See Frahm (1975).

Description and illustrations: See Giacomini (1955: 70, fig. 7-10), Sainsbury (1955: 112-115), Frahm (1974, fig. 2-3).

Distribution (Fig. 3) and Ecology.-C. introflexus is common in temperate and subantarctic regions of the southern hemisphere, between $22^{\circ}$ and $60^{\circ} \mathrm{S}$, from southern South America (South Brazil, Uruguay, Chile, Argentina) eastwards to New Caledonia and New Zealand. Since 1941 the species is found as a neophyte in West and Central Europe (Richards, 1963; Frahm, 1972).

It occurs mainly at low elevations, and prefers temporarily dry to humid, noncalcareous, poor, humous or mineral soil or peat in fairly open situations; it is also found on bases of trees or rotten wood. In Europe the species grows in disturbed habitats where competition is low (Richards, 1963; Frahm, 1972).

Variation (Table 1).-The morphological variation of the gametophyte was adequately described by Giacomini (1955) and Frahm (1974). With respect to sporophyte characteristics, considerable variation is seen in seta length $(5-10 \mathrm{~mm})$. Extremes were found in a collection from New Caledonia (Robbins 3784, L), which in one tuft had setae of 4-5 mm and 9-10 mm! Capsule size was studied by Giacomini (1955), who found that capsules are usually over $1.1 \mathrm{~mm}$ long and 1.6-2.5 times longer than wide. A deviating plant from Uruguay, which has shorter capsules $(0.9-1 \mathrm{~mm}$ long, ca. 1.3 times longer than wide), was described as $C$. introflexus var. brachycarpus Giac. (Montevideo, Felippone 1490, isotype in PC). We found that it differs also in the seta, which is only $4 \mathrm{~mm}$ long, as in C. pilifer. The gametophyte, however, fits $C$. introflexus.

Spores in C. introflexus were never found to be aborted, as opposed to C. pilifer.

\section{EPILOGUE}

Although the number of differentiating characteristics has been reduced in this study, as compared with Giacomini and later authors, a slight overlap is still seen in the remaining key characteristics. We encountered no difficulties in identifying fertile specimens, but a few sterile specimens with lamellae only two cells high were difficult to place. The American, and especially the tropical African, populations of C. pilifer resemble $C$. introflexus much more than do the European ones. This raises the ques- 
tion whether or not the two taxa deserve species rank or should be treated as subspecies (geographic races). Since they have both attained morphological individuality in the gametophyte and the sporophyte, and a pluriregional area of distribution, species rank seems justified. Moreover, the southern hemispheric $C$. introflexus has proved capable of successful invasion into the European area of $C$. pilifer with maintenance of its individuality. Presumed intergradation of the species in the overlap areas in South America and South Africa is a subject for further investigation.

\section{Literature Cited}

Barkman, J. J. \& A. A. Mabelis. 1968. Notes on taxonomy, geography and ecology of the piliferous Campylopus species in the Netherlands and NW. Germany. Collect. Bot. 7: 69-90.

Bizot, M. 1973. Contribution à la Flore Bryologique de Cuba (2e Article). The Bryologist 76: 340-346.

BRIDEL, S. E. 1819. Mantissa. Gotha.

. 1826. Bryologia Universa I: 447-448. Leipzig.

Casares-Gil, A. 1932. Flora Ibérica. Briófitas II. Musgos I. Madrid.

DismiER, M. G. 1909. Première localité française du Campylopus polytrichoides DeNot. fructifié. Bull. Soc. Bot. France 56: 273-276.

FlorschütZ, P. A. \& J. FlorschütZ-DE WAARd. 1974. Studies on Colombian Cryptogams I. Variation of characters in South American species of Campylopus. Jour. Hattori Bot. Lab. 38: $111-114$.

Frahm, J. -P. 1972. Die Ausbreitung von Campylopus introflexus (Hedw.) Brid. in Mitteleuropa. Herzogia 2: 317-330.

1974. Zur Unterscheidung und Verbreitung von Campylopus introflexus (Hedw.) Brid. und C. polytrichoides De Not. Rev. Bryol. Lichénol. 40: 33-44.

- 1975. Conspectus der mittel- und südamerikanischen Campylopus-Arten (Dicranaceae). Bryophyt. Biblioth. 5, 143 p., 14 fig.

GaNGUleE, H. C. 1971. Mosses of Eastern India and adjacent regions. Fasc. 2. Calcutta.

Giacomini, V. 1955. Sull' autonomia specifica e sul ciclo di forme di Campylopus polytrichoides De Not. Atti Ist. Bot. Univ. Lab. Critt. Pavia ser. 5, 13: 45-83.

Grout, A. J. 1937 (1936-39). Moss Flora of North America I. Newfane, Vermont.

Hegewald, E. 1973. Campylopus polytrichoides De Not. with sporophytes in Ireland. Jour. Bryol. 7: 443-444.

JACQUES, E. \& J. LAMBINON. 1968. Campylopus polytrichoides De Not. et C. introflexus (Hedw.) Brid. en Belgique. Bull. Jard. Bot. Nat. Belg. 38: 147-153.

Luisier, A. 1908. Les fruits du Campylopus polytrichoides De Not. Bull. Soc. Portugaise Sc. Nat. 1, 3: 89-91.

RichapDS, P. W. 1963. Campylopus introflexus (Hedw.) Brid. and C. polytrichoides De Not. in the British Isles; a preliminary account. Trans. Brit. Bryol. Soc. 4: 404-417.

SAINSBURY, G. O. K. 1955. A Handbook of the New Zealand Mosses. Royal Soc. New Zealand Bull. 5, $490 \mathrm{p}$.

Sipman, H. J. M. 1977. Campylopus introflexus (Hedw.) Brid. en C. pilifer Brid. in Nederland. Lindbergia 4: 157-160.

TuRner, D. 1804. Muscologiae Hibernicae Spicilegium. Great Yarmouth, London.

VENTURI, G. 1881. Notes sur le Campylopus polytrichoides frutifié et quelques autres mousses de Portugal. Rev. Bryol. Lichénol. 8: 19-20. 